\title{
Do Trench Sediments Affect Great Earthquake Occurrence in Subduction Zones?
}

\author{
LARRY J. RUFF ${ }^{1}$
}

\begin{abstract}
Seismic energy release is dominated by the underthrusting earthquakes in subduction zones, and this energy release is further concentrated in a few subduction zones. While some subduction zones are characterized by the occurrence of great earthquakes, others are relatively aseismic. This variation in maximum earthquake size between subduction zones is one of the most important features of global seismicity. Previous work has shown that the variation in maximum earthquake size is correlated with the variation in two other subduction zone properties: age of the subducting lithosphere and convergence rate. These two properties do not explain all the variance in maximum earthquake size. I propose that a third subduction zone property, "trench sediments", explains part of the remaining variance in maximum earthquake size. Subduction zones are divided into two groups: (1) those with excess trench sediments, and (2) those with horst and graben structure at the trench. Thirteen of the 19 largest subduction zone events, including the three largest, occur in zones with excess trench sediments. About half the zones with excess trench sediments are characterized by great earthquake occurrence. Most of the other zones with excess trench sediments but without great earthquakes are predicted to have small earthquakes by the age-rate correlation. Two notable exceptions are the Oregon-Washington and Middle America zones. Overall, the presence of excess trench sediments appears to enhance great earthquake occurrence. One speculative physical mechanism that connects trench sediments and earthquake size is that excess trench sediments are associated with the subduction of a coherent sedimentary layer, which at elevated temperature and pressure, forms a homogeneous and strong contact zone between the plates.
\end{abstract}

Key words: Subduction zones, great earthquakes, trench sediments.

\section{Introduction}

Most of the largest earthquakes occur in subduction zones and represent the underthrusting of the oceanic lithosphere. Beyond this basic observation, subduction zone seismicity presents many puzzling features. One rather remarkable feature is the variation in maximum earthquake size between subduction zones: this variation is more than three orders of magnitude as measured by the seismic moment. To emphasize this range in characteristic earthquake size, the Chilean

\footnotetext{
${ }^{1}$ Department of Geological Sciences, University of Michigan, Ann Arbor, MI 48109, U.S.A.
} 
subduction zone frequently generates giant earthquakes with fault area dimensions reaching hundreds of kilometers, widespread strong shaking, and destructive tsunamis. On the other hand, underthrusting in the Marianas arc will occasionally generate a magnitude $\approx 7$ earthquake. As another illustration, since the seismic energy release is dominated by the largest events (see, for example, GUTENBERG and RICHTER, 1954), a map of the total seismic energy release in the twentieth century would show a high concentration in some subduction zones while others would be virtually "aseismic". Understanding this variation in large earthquake occurrence is a fundamental pursuit in seismology.

Two lines of inquiry into this subject will be followed: (1) the relationship between maximum earthquake size and other subduction zone "parameters", (2) observations and models of the earthquake rupture process. The above two approaches are not the only lines of study into the subject, but several investigators have made progress using these approaches. The first approach can explain much of the variation in maximum earthquake size, though significant deviations remain. On the other hand, the second approach explains the occurrence of great earthquakes in terms of the strength distribution of the plate interface. In this paper, I propose that the presence or absence of trench sediments forms a link between the two approaches. In particular, trench sediments seem to enhance seismic coupling. I will first briefly review some of the relevant results on seismic coupling and the rupture process, then proceed with a short discussion of trench sediments, and finish with a global survey on the association of excess trench sediments with great earthquakes.

\section{Global Variation in Seismic Coupling}

KANAMORI (1971a) noted that interplate seismic coupling varies systematically in the subduction zones of the northwestern Pacific. He equated the maximum earthquake size in a region with seismic coupling. At that time, KANAMORI explained the variation in seismic coupling by an evolutionary process, whereby the upper plate contact surface degrades. UYEDA and KANAMORI (1979) presented a global perspective and discussed the possible interconnection between several subduction zone parameters. Their paper promoted the approach of "comparative subductology": using global comparisons of the essential characteristics of subduction zones to uncover important aspects of the subduction process. UYEDA and KANAMORI included seismic coupling as an essential characteristic, and suggested that the kinematic parameter of upper-plate absolute velocity exerts a strong influence on coupling. RUFF and KANAMORI (1980) then focussed on seismic coupling, and established that maximum earthquake size is significantly correlated with two parameters: convergence rate and age of the subducting oceanic lithosphere. In particular, great earthquakes tend to occur in subduction zones with 
faster convergence and younger lithosphere, while the relatively aseismic subduction zones are characterized by slower convergence and older lithosphere (see Figure 1). JARRARD (1986) then updated and extended the data set, both in terms of the number of subduction zones and number of parameters, and further confirmed that maximum earthquake size is correlated with oceanic lithosphere age and rate. Although much of the variance in maximum earthquake size is explained by age and rate, there are a few subduction zones that deviate from the overall trend. Thus, there are other factors that influence earthquake size.

Statistical correlations do not necessarily indicate a direct cause and effect relationship. Nevertheless, RUFF and KANAMORI (1980) introduced preferred trajectory as a simple physical mechanism that might explain the above correlation. Plate age and convergence rate directly translate into the preferred vertical and horizontal velocities of the down-going slab. Note that a long-term effect of a steep preferred trajectory, i.e., old lithosphere and slow rate, could be back-arc spreading. Indeed, the subduction zones with recent back-arc spreading activity are characterized by small earthquake size (Figure 1, see RUFF and KanAmORI, 1980). Shallow preferred trajectory might cause large earthquakes by either increasing the tectonic compressive stress or by increasing the fault width as a consequence of a shallow dip angle. Are these mechanisms consistent with our knowledge of the source process of great earthquakes? In the next section, we will see that the current physical model used to explain the earthquake rupture process is not easily related to the above mechanisms.

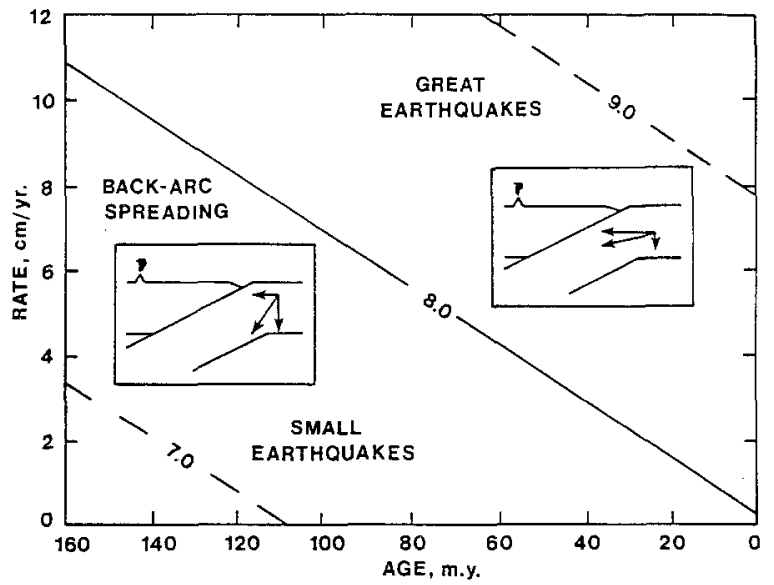

Figure 1

Seismic coupling as a function of lithosphere age and convergence rate (after RUFF and KANAMORI, 1980). Linear regression analysis shows that maximum earthquake size depends on age and rate; the best-fit plane is indicated by the contours of predicted $M_{W}$. Subduction zones that are subducting young lithosphere at a high rate would plot in the upper-right corner, and these zones are characterized by great earthquake occurrence (i.e., $M_{W}>8$ ). The lower-left corner contains subduction zones with smaller earthquakes and back-arc spreading. The insets depict the mechanism of preferred trajectory, whereby age and rate determine the preferred vertical and horizontal velocities of the slab. 


\section{Large Subduction Zone Earthquakes}

\subsection{Seismic Gaps}

Subduction at shallow depths is accommodated by slip across a narrow zone, the plate boundary interface. As subduction proceeds, all segments along the plate boundary must eventually slip, either seismically or aseismically. Plate boundary segments that have previously slipped as large earthquakes are likely to slip again as large earthquakes. Observations indicate that the recurrence intervals between large earthquakes in the same segment vary from less than one to a few hundred years. Hence, future earthquakes are more likely to occur sooner in plate boundary segments with a history of large earthquakes that have not experienced a large earthquake in many decades. This simple yet powerful concept of seismic gaps has been developed and applied to the major plate boundaries, and has successfully forecast the locations of a few large earthquakes (FEDOTOv, 1965; MoGI, 1969; SyKes, 1971; KellehER, 1972; KelleHER et al., 1973; MCCANN et al., 1979; Nishenko and MCCANN, 1981; NishenKo, 1985). Plate boundary segmentation is an essential component of seismic gaps which in part determines the size of the largest earthquakes.

\subsection{Plate Boundary Segmentation}

Underthrusting can occur as seismic slip in the shallow part of the subduction zone, while slip apparently occurs only aseismically below a depth of about $40 \mathrm{~km}$ (see RuFF and KanAmori, 1983a). For the typical shallow dip angle of $10^{\circ}$ to $20^{\circ}$, the potential fault width is one to two hundred kilometers. Major subduction zones extend to thousands of kilometers along the arc system, thus the seismically active part of a plate boundary can be viewed as a long narrow strip that is composed of seismic segments. One of the primary tasks of seismic gap research has been to determine the rupture length of the large plate boundary earthquakes. It is usually assumed that the one-day aftershock area delimits the mainshock rupture area. The one-day aftershock area frequently coincides with the region of uniform and intense shaking. Hence, observations of aftershocks or shaking can identify the seismic segments of a subduction zone. In several cases, the seismic segmentation corresponds to the physiographic segmentation, e.g., major fracture zones or ridges in the oceanic plate form the boundary between two segments.

The overall size of an earthquake is best measured by the seismic moment, defined as $M_{0}=\mu A D$, where $\mu$ is the source region shear modulus, $A$ is the fault area, and $D$ is the average seismic displacement. The moment magnitude scale is directly dependent on the seismic moment $\left(M_{W}=\left(\log M_{0}\right) / 1.5-10.7\right.$, with $M_{0}$ in dyn cm, KANAMORI, 1978). As discussed in KANAMORI and ANDERSON (1975), the average displacement tends to increase as the fault area increases. Thus, in 
general, a larger fault area is equivalent to a larger seismic moment and $M_{W}$. From this perspective, maximum earthquake size depends on those factors that control fault area.

Fault area obviously depends on fault width and length. KeLleHER et al. (1974) claimed that variations in fault width play a dominant role in seismic coupling. They noted that some of the largest earthquakes have occurred in subduction zones with a wide contact zone. They offered support for this claim by measuring the width between the trench and the $70 \mathrm{~km}$ depth contour of the Benioff zone. While their definition of "width" is attractive in that it can be globally measured, unfortunately it does not directly yield the width of the seismogenic zone. To further explore this idea, we can look at the seismogenic width as displayed in the aftershock zones of large earthquakes. The rupture width and length of selected large earthquakes are shown in Figure 2. Aftershock areas are usually determined subjectively by drawing a rectangle or oval around the scattered aftershocks. To obtain a more objective determination, TAJIMA and KANAMORI (1985) devised an energy contour method. I have simply measured the maximum widths and lengths, perpendicular and parallel to the trench axes, of the one-day aftershock regions in TAJIMA and KANAMORI. Two events not in their paper are included in Figure 2, the dimensions for the 1960 Chile event are from Plafker and SAVAge (1970), and the 1957 Aleutian values are taken from House et al. (1981). For the examples presented in Figure 2, it would seem that the variation in fault length is more

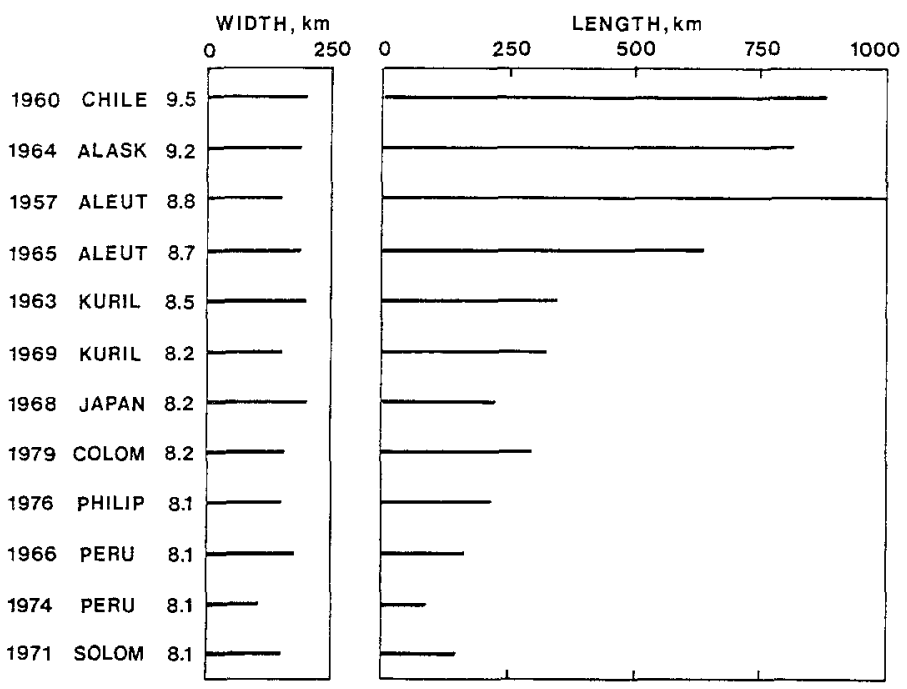

Figure 2

Width and length of the one-day aftershock areas of recent great earthquakes, identified by year of occurrence, region, and $M_{W}$. Except for two exceptions noted in the text, the measurements are based on the aftershock areas of TAJIMA and KANAMORI (1985). Rupture length varies more than rupture width. 
important than the variation in fault width as an explanation for variation in maximum earthquake size.

\subsection{Rupture Length and the Asperity/Barrier Model}

Fault length is a consequence of where the earthquake rupture front starts and stops. The development of the asperity/barrier model gives us a simple physical characterization of earthquake rupture (for example, AKI, 1979; DAS and AKI, 1977; KANAMORI and STEWART, 1978; Nur and IsRaEl, 1980; KANAMORI, 1981; LAY et al., 1982; AKI, 1983; RUFF, 1983; BECK and RUFF, 1984, 1987; SCHWARTZ and RUFF, 1987). The essence of this model is that a fault zone can be characterized by strong and weak regions. The strong regions are called asperities and slip seismically. Slip in the weak regions concentrates the stress at the asperities. The largest earthquake in a seismic segment results from the failure of the largest asperity, or the sequential failure of the largest asperities. The rupture front of the maximum size earthquake can start in either a weak or strong region, but must break the dominant asperity. The rupture front stops either at a major geometric barrier or in a weak region that has previously slipped and therefore is not highly stressed. Major geometric barriers include drastic kinks in the plate boundary strike or changes in plate boundary type.

The asperity/barrier model provides a qualitative physical connection between seismic segmentation and the earthquake rupture process. This connection leads to some interesting consequences. Figure 3 shows two hypothetical strength distributions along a subduction zone. The distribution with small isolated strong points would cause small localized rupture areas, while the distribution with a relatively constant strength would result in a large rupture length. Thus, strong seismic coupling depends more on the "smoothness" of the strength distribution than on the peak value of the strength. This view is supported by the apparent smoothness of the rupture process of the 1964 Great Alaskan earthquake (see RuFF and KANAMORI, 1983b).

The above discussion is not a comprehensive review of all the research on fault heterogeneity, nor does it present all viewpoints on the rupture process. Given this qualifier, I state the following conclusion: stronger seismic coupling is caused by a smoother strength distribution along the seismogenic zone. How does this conclusion relate to our earlier considerations on the global variation in seismic coupling? Are there any mechanisms that relate lithosphere age and convergence rate to fault strength distribution? RUFF and KANAMORI (1983a) noted two facts relevant to the above questions: (1) the old lithosphere subducting in the Marianas is characterized by rough ocean-floor topography, (2) the two largest earthquakes (1960 Chilean and 1964 Alaskan events) occurred in segments that seem to have "excess trench sediments". If a rough ocean-floor topography translates into highly heterogeneous strength distribution, then the first fact would explain the relatively aseismic nature 


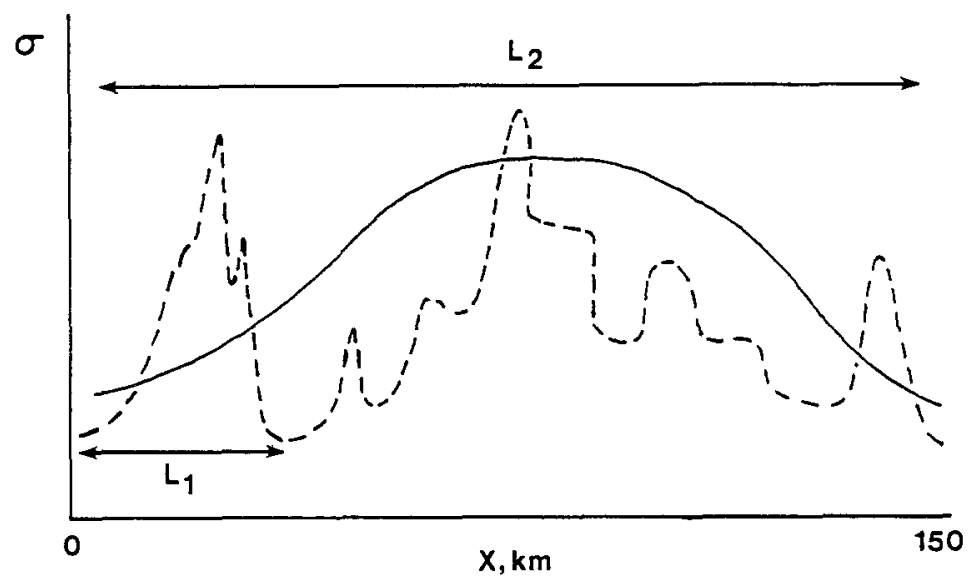

Figure 3

Two hypothetical strength distributions along a fault: smooth (solid line) and irregular (dashed). Each distribution is plotted as failure stress $(\sigma)$ versus distance along the fault zone. Slip occurs when the tectonic stress level reaches the failure stress. Slip in the weaker regions transfers stress to the strong regions. Since the strongest regions in the irregular distribution are isolated, the earthquakes that eventually break these regions have a rather small rupture dimension $\left(L_{1}\right)$. For the relatively smooth distribution, the dimension of the strong region is larger, hence the earthquake will have a greater rupture length $\left(L_{2}\right)$.

of the Marianas subduction zone. If we allow the interpretative leap that the presence of excess trench sediments is related to a smoother strength distribution, then the second fact would explain the two giant earthquakes. The main thrust of this paper is to pursue the possible contribution of excess trench sediments. Rather than analyze just one or two trench segments, I will adopt the comparative subductology attitude and present a global survey. The term "excess trench sediments" will first be defined and developed.

\section{Excess Trench Sediments}

Even in their pioneering plate tectonics paper, IsACKs et al. (1968) made some provision for sediment subduction. At first glance, the tectonic role of sediments appears to be a minor one. Sediments do however significantly impact geology, geochemistry, and geophysics: many geological terranes are thought to be exumed trench sediments; recycling of crustal material via sediment subduction affects the geochemical evolution of the mantle; and as promoted in this paper, sediments may influence subduction zone seismicity.

Sediments are transported into the trench region from both the oceanic plate and island arc sides. There are two apparently contradictory views on the fate of these sediments: (1) the sediments are subducted along with the down-going plate, 
(2) sediments riding on the oceanic plate are scraped off and deposited; the accretionary prism contains the accumulated oceanic sediments along with continent-derived sediments. We now know that both views are correct. That is, some subduction zones are presently subducting all available sediments while others seem to be actively constructing accretionary prisms (see e.g., KLUM and FOWLER, 1974; KARIG and Sharman, 1975; SCHOll et al., 1977; SCHOll et al., 1980; VON HUENE et al., 1982; HILDE, 1983). In some subduction zones, not only are the available sediments being subducted, but the sediment subduction process is apparently eroding the upper-plate in the trench region. In many of these subduction zones, the down-going oceanic plate develops a horst and graben structure between the outer-rise and the trench. This structure frequently strikes parallel to the trench axis, and is thought to result from tensional stresses associated with plate bending (see CHAPPLE and FORSYTH, 1979). One proposed mechanism for sediment subduction is that the horst and graben structure provides "buckets" that fill up with sediments, which are then carried down the subduction zone (Figure 4, for a discussion of this mechanism, see HILDE, 1983). If the available sediments do not fill the graben "buckets", then the leading edge of the upper plate erodes to provide

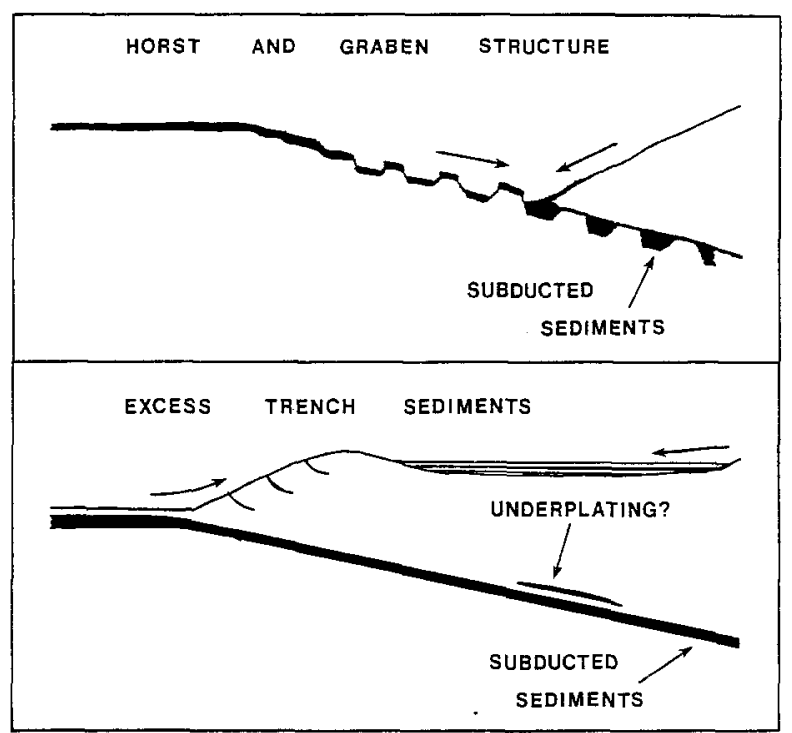

Figure 4

Two trench morphologies and possible mechanisms of sediment subduction. These graphs are schematic and not to scale, but the depth of the grabens is typically $<1 \mathrm{~km}$, and the horizontal dimension is approximately $10 \mathrm{~km}$, hence the seismogenic zone is off to the right. A well-developed horst and graben structure provides "buckets" which can erode the upper-plate and carry down sediments. In contrast, one of the characteristics of excess trench sediments is that sediments are added to the upper-plate and form an accretionary prism. The role of underplating is not known. At this time, it is only speculation that zones with excess trench sediments subduct a coherent sedimentary layer that serves as a smooth contact zone between the plates. 
the requisite material. At the other end of the spectrum are those subduction zones that accumulate sediments. This can happen in three ways: (1) the oceanic sediments are scraped off and are added to the front of the rapidly deforming accretionary prism, (2) continent-derived sediments are deposited on top of the accretionary prism, or they spill into the trench and are added to the highly deformed front, (3) sediments that are initially subducted then underplate the bottom of the accretionary prism. Note that sediment subduction may occur even if the accretionary prism is growing. Accretionary prisms form where the sediment supply rate is greater than the sediment subduction rate. There is no complete global assessment of the relative rates of sediment supply and subduction. Although it is thought that most oceanic sediments are subducted, there are dissenting opinions (for discussion, see ARMSTRONG, 1981; KARIG and KAY, 1981).

The horst and graben structure is not found in subduction zones with extensive accretionary prisms (HILDE, 1983). Perhaps the horsts and grabens are buried by the excess sediments, or maybe the horst and graben structure does not exist at all. Studies of the southern Caribbean arc indicate that the incoming oceanic sediments are split, the upper portion is added to the accretionary prism while the lower portion is apparently subducted undeformed (e.g., Busu-Duval et al., 1982). If we assume that the horst and graben formation is suppressed, then the lower sedimentary portion could remain undeformed. The contact between the plates would then be composed of coherent layered sediments, as opposed to the "bucket" mechanism where the contact material alternates between basaltic crust and chaotic sediments (Figure 4). If coherent layered sediments enhance seismic coupling at deeper depths, then the metamorphosed oceanic sediments must be capable of seismic failure at elevated temperatures and pressures. There are some indications that this may be possible (WANG, 1980). Thus, the mechanism of sediment subduction might significantly affect the seismic strength distribution along the contact zone between the plates.

My use of the term "excess trench sediments" refers to the presence of an accretionary prism and, generally, the absence of the horst and graben structure. Excess trench sediments then closely coincides with HILDE's (1983) classification of thick trench deposits. The main distinction between these two terms is the speculative implication that I attach to excess trench sediments. In future discussion, excess trench sediments will be equated with a smooth strength distribution. I emphasize that this identification should be treated with some skepticism, but I assert that it is at least plausible.

\section{Global Comparison of Trench Sediments and Large Earthquakes}

The division of subduction zones into the binary classification of "excess trench sediments" and "horst-graben structure" certainly has a subjective element. The 
global survey by HILDE (1983) at least provides an independent classification. As previously noted, I equate HILDE's thick trench sediments with excess trench sediments (ETS). The major subduction zones with ETS are shown in Figure 5. More than half of the surveyed subduction zones are classified as zones with ETS. We shall test the hypothesis that excess trench sediments promote the occurrence of large and great earthquakes. If trench sediments were quantified by a continuous variable, then we could simply test the correlation between trench sediments and maximum earthquake size for all subduction zones. Given our binary classification scheme, we seek significant differences between the two populations. There are two types of tests: (1) do great earthquakes occur in subduction zones with or without excess trench sediments; (2) are subduction zones with excess trench sediments characterized by great or small earthquakes.

The data for the first test are listed in Table 1. The primary source for the earthquake data is the list in KANAMORI (1977), with two modifications from the updated list in KANAMORI (1983) (specifically, the 1923 Kamchatka and 1979 Colombia events). There is one other change, the $M_{W}$ value for the 1957 Great

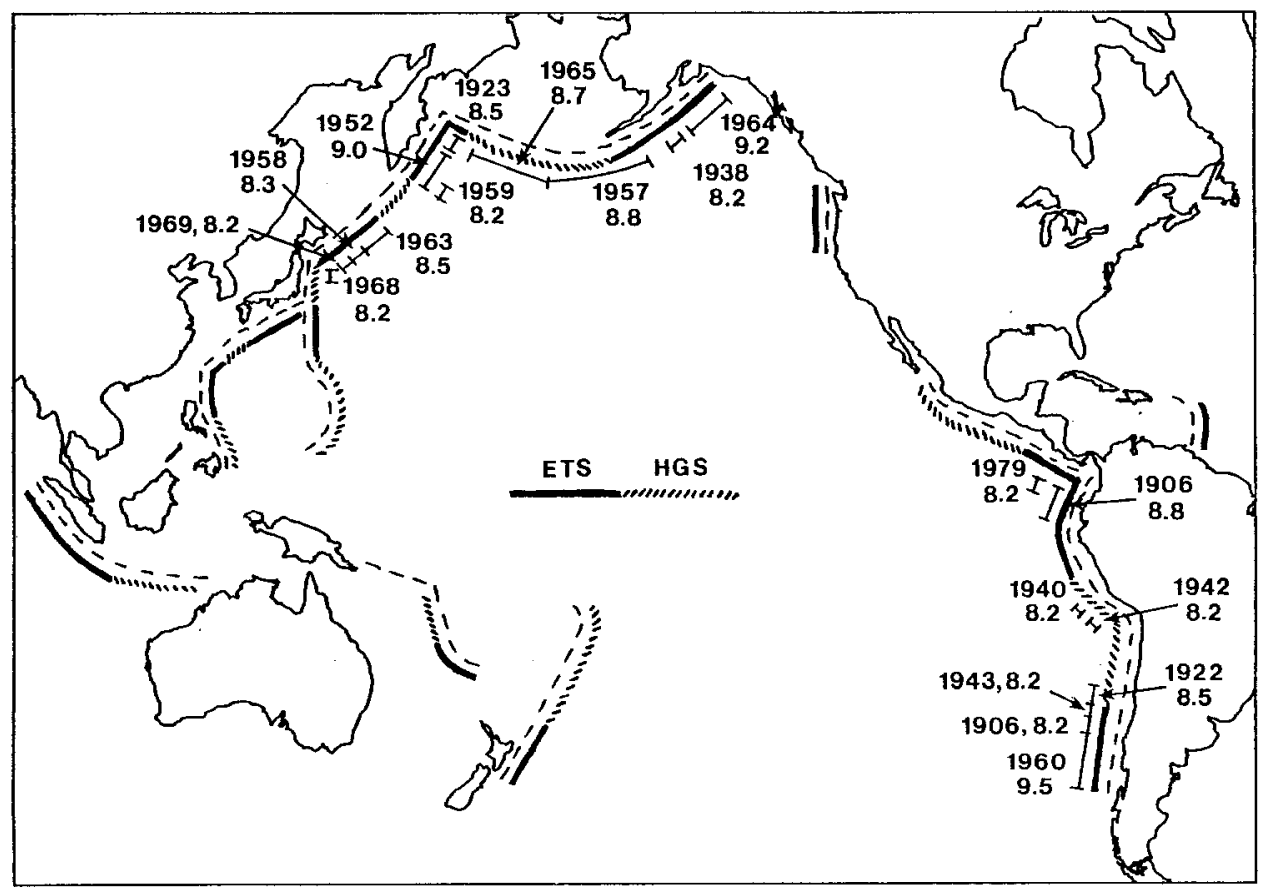

Figure 5

World map showing the trench sediment classification of the major subduction zones. Also shown are the year, $M_{W}$, and approximate rupture length of the largest underthrusting earthquakes. Zones are classified either as ETS (excess trench sediments) or HGS (horst and graben structure). The trench sediment classification is largely based on the map in HILDE (1983). 
Table 1

Great subduction zone underthrusting earthquakes with $M_{W} \geq 8.2$. $A$ cross in the ETS column indicates excess trench sediments.

\begin{tabular}{llll}
\hline \multicolumn{1}{c}{ Region } & \multicolumn{1}{c}{ Date } & $M_{W}$ & ETS \\
\hline Southern Chile & May 22, 1960 & 9.5 & X \\
Alaska & March 28, 1964 & 9.2 & X \\
Kamchatka & Nov. 4, 1952 & 9.0 & X \\
Aleutians & March 9, 1957 & 8.8 & \\
Colombia-Ecuador & Jan. 31, 1906 & 8.8 & X \\
Aleutians & Feb. 4, 1965 & 8.7 & \\
Kurile Islands & Oct 13, 1963 & 8.5 & X \\
Central Chile & Nov. 11, 1922 & 8.5 & \\
Kamchatka & Feb. 3, 1923 & 8.5 & X \\
Kurile Islands & Nov. 6, 1958 & 8.3 & X \\
Chile & Aug. 17, 1906 & 8.2 & X \\
Alaska & Nov. 10, 1938 & 8.2 & X \\
Kamchatka & May 4, 1959 & 8.2 & X \\
Colombia & Dec. 12, 1979 & 8.2 & X \\
Northern Honshu & May 16, 1968 & 8.2 & \\
Peru & May 24, 1940 & 8.2 & \\
Peru & Aug. 24, 1942 & 8.2 & \\
Central Chile & April 6, 1943 & 8.2 & X \\
Kurile Islands & Aug. 11, 1969 & 8.2 & X \\
\hline
\end{tabular}

Aleutian event has been reduced from 9.1 to $8 \frac{3}{4}$ (RUFF et al., 1985). There are several great earthquakes listed in KANAMORI (1983) that do not appear in Table 1, three earthquakes are intraplate events in central Asia, two are thought to be strike-slip events (1958 Alaska, and 1938 Banda Sea, see BEN-MENAHEM, 1977), and two subduction zone events represent intraplate normal faulting in the oceanic lithosphere (1933 Sanriku, and 1977 Java, see KANAMORI, 1971; FITCH et al., 1981; SPENCE, 1986). The nineteen earthquakes in Table 1 are thought to be all of the underthrusting subduction events in the twentieth century with a documented $M_{W}$ of 8.2 or larger. While the sediment classification for most of the earthquakes is straightforward, a few events need some discussion. A close examination of Figure 5 reveals that the rupture zones of the two great Aleutian events include segments with excess sediments. However, most of the moment release for both events occurs outside these regions, thus these events do not receive the ETS classification. Sediments in southern Chile are apparently transported northward along the trench axis (KuLM et al., 1977), and consequently thin to the north. Hence there is some ambiguity where to end the ETS classification in central Chile. Using additional information given in KuLM et al. (1977), I have placed the dividing line between the 1943 and 1922 rupture zones, broadly consistent with HILDE's map. Figure 6 compares the distribution of earthquake size for zones with and without excess sediments. More than half of the earthquakes, 13 out of 19, are associated with 


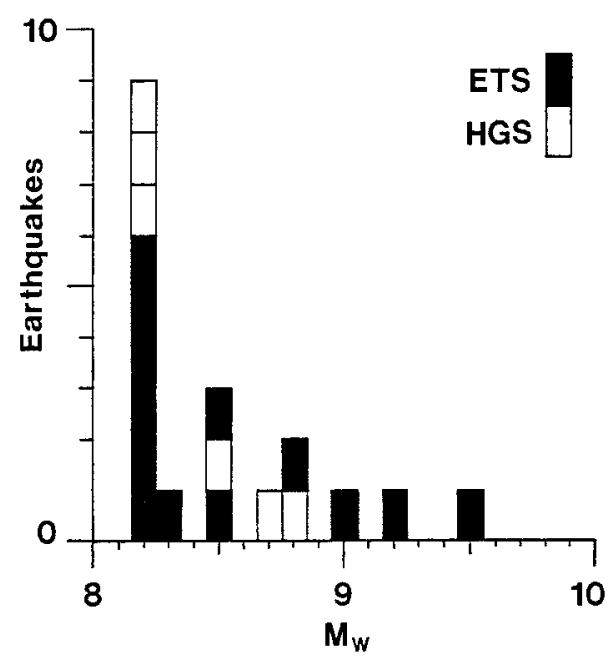

Figure 6

Histogram of the 19 largest underthrusting subduction zone earthquakes, plotted as a function of $M_{W}$. There are two groups of earthquakes: those that occur in zones with excess trench sediments (ETS), and those that occur in zones with horst and graben structure (HGS). Most of the largest earthquakes occur in ETS zones.

excess trench sediments. It seems that most of the largest earthquakes occur in regions of excess sediments with the strong exception of the two great Aleutian earthquakes. Due in part to the large number of $M_{W}=8.2$ events, the mean $M_{W}$ values for the two groups are not significantly different. A preliminary conclusion is that great earthquakes tend to occur in zones with excess sediments, but not exclusively.

The other test is to examine the maximum earthquake size of all zones with excess trench sediments. There are subduction zones in Figure 5 with ETS that are not represented by any earthquakes in Table 1 . These zones are Southern Honshu, Sumatra, Caribbean, New Zealand-Kermadec, Izu-Bonin, Taiwan-Philippines, New Hebrides, Middle America (south of Mexico), and Oregon-Washington (USA). If these zones have had no great earthquakes in the twentieth century, can we immediately claim that these zones are characterized by the lack of great earthquakes? This question opens the difficult issue of whether the twentieth century catalog of great earthquakes can be regarded as characteristic. If the recurrence interval between the largest earthquakes in some subduction zone is greater than 100 years, then the maximum size earthquake may be missing from the twentieth century catalog. While this problem may also apply to zones that have registered a great earthquake, we will only examine the historical record for the zones with ETS that lack a great earthquake. 
It appears that at least two of the above zones, the Southern Honshu and Sumatra zones, are characterized by great earthquakes. Two earthquakes with $M_{W}=8.1$ have occurred in the Southern Honshu zone, in 1944 and 1946. Hence, the exclusion of Southern Honshu from Table 1 results from the arbitrary magnitude threshold. There is an excellent historical record in this region; it is likely that one or both of the great earthquakes in 1854 would be above the 8.2 magnitude threshold, and presumably the great earthquake in 1707 would also be 8.2 or larger (ANDO, 1975). Turning to the Sumatra zone, NewCOMB and MCCANN (1987) document the occurrence of two great earthquakes in the nineteenth century, the 1833 and 1861 events with probable rupture lengths of 500 and $300 \mathrm{~km}$, respectively. On the basis of rupture length, they assign a $M_{W}$ on the order of $83 / 4$ to the 1833 event. This $M_{W}$ value is consistent with the rupture length versus $M_{W}$ plot in Figure 2. The lack of Sumatran great earthquakes in the twentieth century can be explained by a recurrence interval greater than 150 years.

The historical record for the Caribbean indicates that a large event occurred in the northern part of the Lesser Antilles arc in 1843 (see KELLEHER et al., 1973). With a rupture length of $200-250 \mathrm{~km}$, this event should be close to the 8.2 magnitude threshold of Table 1. Thus, the Caribbean arc seems capable of generating at least a magnitude 8 event. Although the accretionary prism is less developed at the location of the 1843 event, the ETS classification is given to the entire zone. NiSHENKo and MCCANN (1981) suggest that the New Zealand earthquake that occurred in 1833 has a rupture length of approximately $200 \mathrm{~km}$. Thus, New Zealand can also generate an earthquake close to the 8.2 magnitude threshold.

There is no evidence of a great subduction event in the Izu-Bonin arc. There are no earthquakes along the Taiwan-Eastern Philippines trench with a documented $M_{W}$ greater than 8. Likewise, no great earthquakes in the New Hebrides or Middle America regions are known.

The seismic hazard of the Oregon-Washington region is currently an active issue (e.g., Heaton and Kanamori, 1984; and see Heaton and Hartzell, this volume). There are no great, or even large, earthquakes in this region in the twentieth century. Assessment of the previous activity is hampered by a limited historical record and the long recurrence interval for a great earthquake. Although this zone may be capable of generating a great earthquake, for the present concerns of a global survey, Oregon-Washington zone is listed as aseismic.

In summary, of the 14 distinct regions with excess sediments, 7 zones appear to generate great earthquakes, 2 appear to be borderline cases (Caribbean and New Zealand-Kermadec), and 5 do not generate great earthquakes. Thus, the subduction zones with great earthquakes do not form an overwhelming majority of the ETS subduction zones. 
PAGEOPH,

\subsection{Effect of Plate Age and Convergence Rate}

To review our findings: most great earthquakes occur in zones with excess sediments, and about half of the subduction zones with excess sediments have great earthquakes. Clearly there is not a one-to-one correspondence between excess trench sediments and great earthquakes. The lack of a one-to-one correspondence implies that other factors influence earthquake size. At this point, it is instructive to place trench sediments within the framework of the established global correlation for maximum earthquake size.

Those zones with ETS but no great earthquakes have another feature in common: they plot in the lower-left corner of Figure 1 (except for Oregon-Washington and Middle America). This association implies that age and rate determine the potential for a great earthquake, hence a subduction zone that falls in the lower-left corner of Figure 1 may not generate a great earthquake regardless of excess trench sediments. The best-fit plane from the linear regression in RUFF and KANAMORI (1980) is used to calculate a predicted $M_{W}$ from the age and rate values for each subduction zone (Table 2). The observed maximum $M_{W}$ is plotted versus the

Table 2

Maximum earthquake size in subduction zones: Observed (Obs), Predicted (Pre), Residual (Obs - Pred), Zones with Excess Trench Sediments $(X)$.

\begin{tabular}{|c|c|c|c|c|}
\hline Zone & $M_{W}(\mathrm{Obs})$ & $M_{W}(\mathrm{Pre})$ & Residual & ETS \\
\hline Southern Chile & 9.5 & 9.3 & 0.2 & $\mathbf{X}$ \\
\hline Central Chile & 8.5 & 9.0 & -0.5 & \\
\hline Peru & 8.2 & 8.9 & -0.7 & \\
\hline Ecuador-Colombia & 8.8 & 8.8 & 0.0 & $\mathrm{X}$ \\
\hline Central Am. (Mexico) & 8.1 & 8.6 & -0.5 & \\
\hline Kamchatka & 9.0 & 8.5 & 0.5 & $\mathrm{X}$ \\
\hline Aleutians & 8.8 & 8.4 & 0.4 & \\
\hline Alaska & 9.2 & 8.4 & 0.8 & \\
\hline Kurile Islands & 8.5 & 8.3 & 0.2 & $\mathrm{X}$ \\
\hline Taiwan-Philippines & 8.0 & 8.2 & -0.2 & $\mathrm{X}$ \\
\hline Sumatra & 8.7 & 8.2 & 0.5 & $\mathrm{x}$ \\
\hline Northern Honshu & 8.2 & 8.1 & 0.1 & \\
\hline Tonga & 8.3 & 8.1 & 0.2 & \\
\hline Java & 7.1 & 7.8 & -0.7 & \\
\hline Kermadec & 8.1 & 7.8 & 0.3 & $\mathrm{X}$ \\
\hline New Zealand & 8.0 & 7.6 & 0.4 & $\mathrm{X}$ \\
\hline New Hebrides & 7.9 & 7.8 & 0.1 & $\mathrm{X}$ \\
\hline Scotia & 7.1 & 7.7 & -0.6 & \\
\hline Izu-Bonin Islands & 7.2 & 7.4 & -0.2 & $\mathrm{X}$ \\
\hline Caribbean & 8.0 & 7.3 & 0.7 & $\mathrm{X}$ \\
\hline Marianas & 7.2 & 7.2 & 0.0 & \\
\hline Southern Honshu & 8.3 & 8.3 & 0.0 & $\mathrm{X}$ \\
\hline Middle America & 7.5 & 8.4 & -0.9 & $\mathrm{X}$ \\
\hline Oregon-Washington & $<7.0$ & 8.3 & -1.3 & $\mathrm{X}$ \\
\hline
\end{tabular}




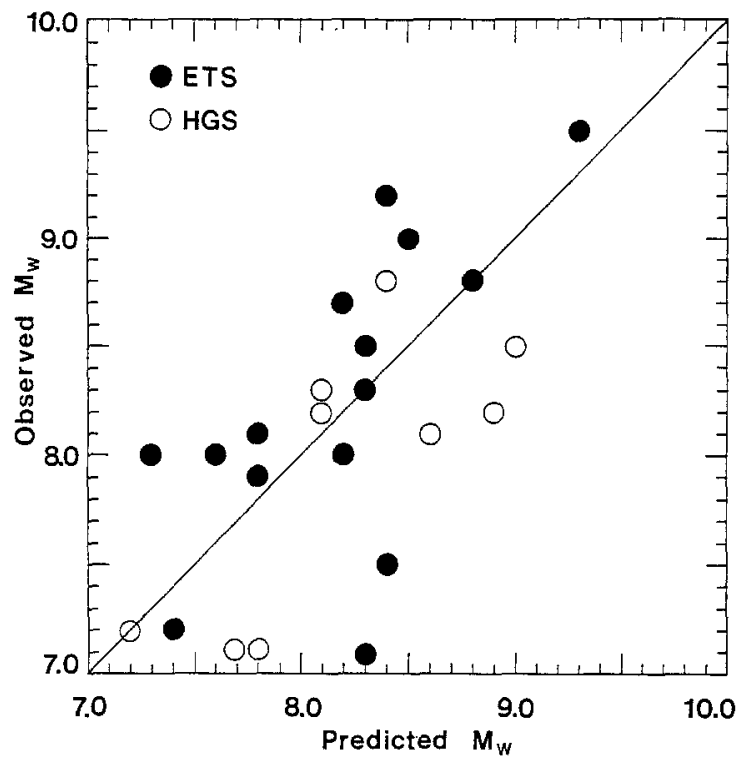

Figure 7

Observed maximum earthquake size versus the size predicted by the linear combination of convergence rate and lithosphere age (see Figure 1, and RUFF and KANAMORI, 1980). If age and rate exactly predicted the observed $M_{W}$, then all subduction zones would plot on the diagonal line. The two groups of subduction zones are: excess trench sediments (ETS) and horst and graben structure (HGS).

predicted value in Figure 7. KANAMORI (1983) shows a similar plot for the time/space normalized $M_{W}$. The predicted values for the maximum and normalized $M_{W}$ are nearly identical (compare Figures 2 and A1 in RUFF and KANAMORI, 1980). The observed values in Figure 7 are the same as in RUFF and KANAMORI (1980) except for the revised values for the Aleutians, Sumatra, Caribbean, and New Zealand, and the addition of Southern Honshu, Middle America (south of Mexico), and Oregon-Washington. Figure 8 plots the observed $M_{W}$ values from Figure 7 and shows the large range in maximum earthquake size for zones with sediments, as previously concluded. We now "correct" for the effect of age and rate by plotting the variation from the predicted values (Figure 9). A positive value corresponds to a maximum earthquake size larger than the predicted number. The two populations in Figure 9 appear to be distinct, though the standard errors about the means overlap.

The Oregon-Washington and Middle America zones violate the trend that ETS zones with no great earthquakes plot in the lower-left corner of Figure 1. Are they true exceptions, or have great earthquakes occurred before the historical records began? This important question cannot be answered here, except that to say that this study supports the concerns of HEATON and KANAMORI (1984). 


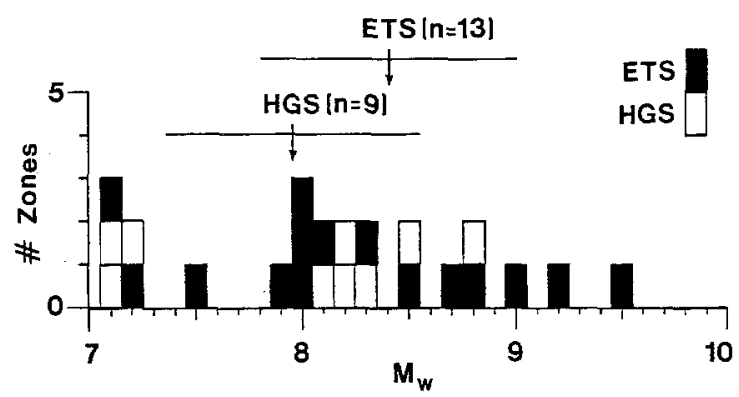

Figure 8

Histogram of the maximum earthquake size of subduction zones. Also plotted are the means and standard errors of the ETS and HGS groups. Of the 24 subduction zones, 15 are classified as ETS zones. The mean and standard error for the ETS zones are based on 13 zones, Oregon-Washington and Middle America are excluded (see text).

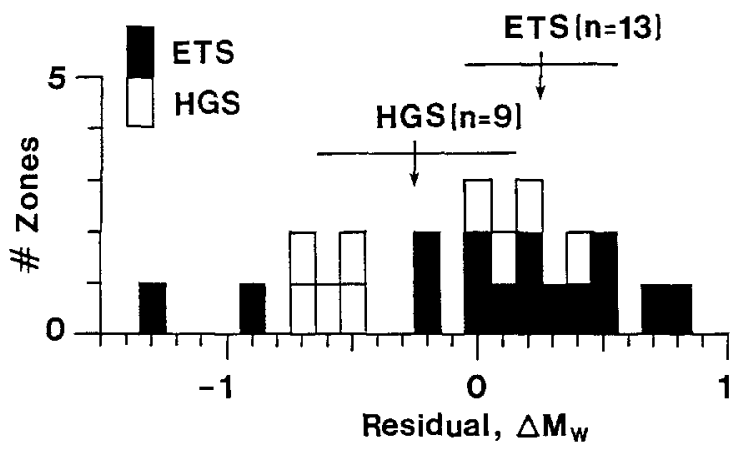

Figure 9

Histogram of the residual $M_{W}$ of subduction zones. The residuals are the variation from the predicted trend in Figure 7. The means and standard errors of the residuals are plotted for the ETS and HGS zones. As in Figure 8, the Oregon-Washington and Middle America zones are excluded from the mean. The ETS and HGS means are better separated than in Figure 8; this suggests that trench sediments may explain part of the variation in earthquake size about the age-rate prediction.

\section{Discussion and Conclusions}

The global survey of great earthquakes and subduction zones shows that most great earthquakes occur in subduction zones with excess trench sediments (ETS), and about half of the zones with ETS are characterized by great earthquake occurrence. Also, the mean $M_{W}$ value is higher for the population of great earthquakes in zones with ETS. If we were only concerned with the global distribution of the 19 largest earthquakes, we might conclude that excess trench sediments explain great earthquake occurrence, with just a few exceptions. This conclusion is weakened by the observation that many zones with ETS have no great 
earthquakes. Hence, excess trench sediments do not always cause great earthquakes, neither are they the sole cause of great earthquakes. There must be other factors. The established correlation of maximum earthquake size with age and rate provides the complimentary factor: the zones with ETS but without great earthquakes have low $M_{W}$ values predicted from age and rate (except for two zones). The quantitative significance of age and rate can be assessed by comparing Figures 8 and 9 . Application of the age-rate "correlation" better separates the two populations. Therefore, the overall conclusion is that the variation in maximum earthquake size depends on at least three variables: plate age, convergence rate, and excess trench sediments. The association between the largest earthquakes and excess trench sediments can then be attributed to the enhancement of $M_{W}$ in those ETS zones with high seismic potential.

Recall the proposed chain of cause-and-effect mechanisms that connects trench sediments to earthquake size: excess trench sediments $\rightarrow$ subduction of a coherent sedimentary layer $\rightarrow$ smooth seismic strength distribution $\rightarrow$ large earthquake rupture area. Although this chain of mechanisms is presently untested, future studies can critically examine these speculations.

RUFF and KANAMORI (1980) suggested that age and rate affect seismic coupling through preferred trajectory. Now that sediments and smooth strength distributions are invoked to cause great earthquakes, a new possibility is that age and rate influence the sediment subduction process. For example, suppression of the horst and graben structure may be an important component in achieving a smooth strength distribution; perhaps the horst and graben structure is more easily suppressed in rapidly subducting young lithosphere.

Plate tectonics explains why there are underthrusting earthquakes in subduction zones, but it cannot explain the global variation in the size of these earthquakes. This fundamental problem is still unsolved. Indeed, given the sketchy nature of the physical mechanisms, I will not claim that the three factors of age, rate, and sediments control earthquake size. I will also admit that the statistical correlation between excess sediments and great earthquake occurrence is less than compelling. However, at the very least, the association between excess trench sediments and great earthquakes should dispel the commonly expressed notion that sediments cause aseismic subduction. It is my hope that the assumptions and speculations in this paper will be probed and tested.

\section{Acknowledgments}

The program in earthquake studies at the University of Michigan is supported by the National Science Foundation (Grants EAR-8407786 and P.Y.I./EAR8351515 to LJR). My thanks to the Maurice Ewing Symposium program for the opportunity to present these ideas to rock mechanics. 


\section{REFERENCES}

AKI, K. (1979), Characterization of barriers on an earthquake fault, J. Geophys. Res. 84, 6140-6148.

AKI, K., Strong-motion seismology, in Earthquakes: Observation, Theory, and Interpretation (edited by H. Kanamori and E. Boschi) (North Holland, New York 1983) pp. 223-250.

ANDO, M. (1975), Source mechanisms and tectonic significance of historical earthquakes along the Nankai trough, Japan, Tectonophysics 27, 119-140.

ARMSTRONG, R. C. (1981), Radiogenic isotopes: the case for crustal recycling on a near-steady-state no-continental-growth earth, Phil. Trans. Roy. Soc. London A301, 443-472.

BECK, S. L. and L. J. RUFF (1984), The rupture process of the great 1979 Colombia earthquake: evidence for the asperity model, J. Geophys. Res. 89, 9281-9291.

BECK, S. L. and L. J. RUFF (1987), Rupture process of the great 1963 Kurile Islands earthquake sequence: asperity interaction and multiple event rupture, J. Geophys. Res. 92, 14,123-14,138.

Ben-Menahem, A. (1977), Renormalization of the magnitude scale, Phys. Earth Planet. Int. 15, 315-340.

Buju-Duval, B., P. Le Quellec, A. MAsCle, V. Renard, and P. Valery (1982), Multibeam bathymetric survey and high resolution seismic investigations on the Barbados Ridge complex (eastern Caribbean): A key to the knowledge and interpretation of an accretionary wedge, Tectonophysics 86, 275-304.

ChAPPLE, W. M. and D. W. Forsyth (1979), Earthquakes and bending of plates at trenches, J. Geophys. Res. 84, 6729-6749.

DAS, S. and K. AKI (1977), Fault planes with barriers: A versatile earthquake model, J. Geophys. Res. 82, $5658-5670$.

FEDotov, S. A. (1965), Regularities of the distribution of strong earthquakes of Kamchatka, the Kurile Islands, and northeastern Japan, Trudy Inst. Fiz. Zemli Akad. Nauk. SSSR 36, 66-93.

FITCH, T. J., R. G. NORTH, and M. W. SHIELDS (1981), Focal depths and moment tensor representations associated with the great Sumba earthquake, J. Geophys. Res. 86, 9357-9374.

Gutengerg, B. and C. F. Richter, Seismicity of the Earth (Princeton University Press, Princeton, N.J., 2nd ed., 1954) $310 \mathrm{pp}$.

HeAton, T. H. and S. H. HARTzell (1988), Estimation of strong ground motions from hypothetical earthquakes on the Cascadia subduction zone, Pacific Northwest, Pure and Appl. Geophys. 129, 1/2, 133-203.

Heaton, T. H. and H. KanAmOri (1984), Seismic potential associated with subduction in the northwestern United States, Bull. Seism. Soc. Am. 74, 933-941.

HiLdE, T. W. C. (1983), Sediment subduction versus accretion around the Pacific, Tectonophysics 99, $381-397$.

HOUSE, L. S., L. R. SYKES, J. N. DAVIES, and K. H. JACOB, Identification of a possible seismic gap near Unalaska Island, eastern Aleutians, Alaska, in Earthquake Prediction, an International Review (edited by D. W. Simpson and P. G. Richards) (American Geophysical Union, Washington, D.C. 1981) pp. $81-92$.

IsACKs, B., J. Oliver, and L. SyKes (1968), Seismology and the new global tectonics, J. Geophys. Res. $73,5855-5899$.

JARRARD, R. D. (1986), Relations among subduction parameters, Rev. Geophys. 24, 217-284.

KANAMORI, H. (1971a), Great earthquakes at island arcs and the lithosphere, Tectonophysics 12, $187-198$.

KANAMORI, H. (1971b), Seismological evidence for a lithospheric normal faulting-the Sanriku earthquake of 1933, Phys. Earth Planet. Int. 4, 289-300.

KANAMORI, H. (1977), The energy release in great earthquakes, J. Geophys. Res. 82, 2981-2987.

KANAMORI, H. (1978), Quantification of earthquakes, Nature 271, 411-414.

KANAMORI, H., The nature of seismicity patterns before large earthquakes, in Earthquake Prediction, an International Review (edited by D. W. Simpson and P. G. Richards) (American Geophysical Union, Washington D.C., 1981) pp. 1-19.

KANAMORI, H., Global seismicity, in Earthquakes: Observation, Theory, and Interpretation (edited by H. Kanamori and E. Boschi) (North Holland, New York, 1983) pp. 596-608.

KANAMORI, H. and D. L. ANDERSON (1975), Theoretical basis of some empirical relations in seismology, Bull. Seism. Soc. Am. 65, 1073-1095. 
KANAmori, H. and G. S. STEwart (1978), Seismological aspects of the Guatemala earthquake of February 4, 1976, J. Geophys. Res. 83, 3427-3434.

KARIG, D. E. and R. W. KAY (1981), Fate of sediments on the descending plate at convergent margins, Phil. Trans. Roy. Soc. London A301, 443-472.

KARIG, D. E. and G. F. ShARMAN (1975), Subduction and accretion in trenches, Geol. Soc. Am. Bull. $86,377-389$.

Kelleher, J. (1972), Rupture zones of large South American earthquakes and some predictions, J. Geophys. Res. 77, 2087-2103.

Kelleher, J., J. SAvino, H. Rowlett, and W. MCCANN (1974), Why and where great thrust earthquakes occur along island arcs, J. Geophys. Res. 79, 4889-4899.

Kelleher, J., L. Sykes, and J. Oliver (1973), Possible criteria for predicting earthquake locations and their application to major plate boundaries of the Pacific and the Caribbean, J. Geophys. Res. 78, 2547--2585.

KULM, L. D. and G. A. FowleR, Oregon continental margin structure and stratigraphy-a test of the imbricate thrust model, in The Geology of Continental Margins (edited by C. A. Burk and C. L. Drake) (Springer, New York, 1974) pp. 261-283.

Kulm, L. D., W. J. SChWEller, and A. MASIAS, A preliminary analysis of the subduction processes along the Andean continental margin, $6^{\circ}$ to $45^{\circ} S$, in Island Arcs, Deep Sea Trenches, and Back-Arc Basins (edited by M. Talwani and W. C. Pitman III) (American Geophysical Union, Washington D.C., 1977) pp. 285-302.

LAY, T., H. KANAMORI, and L. RUFF (1982), The asperity model and the nature of large subduction zone earthquakes, Earthquake Pred. Res. 1, 3-71.

MCCANN, W. R., S. P. Nishenko, L. R. Sykes, and J. Kraus (1979), Seismic gaps and plate tectonics: Seismic potential for major plate boundaries, PAGEOPH 117, 1087-1147.

MoGI, K. (1969), Relationship between the occurrence of great earthquakes and tectonic structures, Bull. Earthquake Res. Inst., Tokyo Univ. 47, 429-451.

NewComb, K. R. and W. R. MCCANN (1987), Seismic history and seismotectonics of the Sunda arc, J. Geophys. Res. 92, 421-439.

NISHENKO, S. P. (1985), Seismic potential for large and great interplate earthquakes along the Chilean and southern Peruvian margins of South America: A quantitative reappraisal, J. Geophys. Res. 90, 3589-3616.

Nishenko, S. P. and W. R. MCCANn, Seismic potential for the world's major plate boundaries: 1981, in Earthquake Prediction, an International Review (edited by D. W. Simpson and P. G. Richards) (American Geophysical Union, Washington D.C., 1981) pp. 20-28.

Nur, A. and M. Israel (1980), The role of heterogeneities in faulting, Phys. Earth Planet. Int. 21, $225-236$.

Plafker, G. and J. C. SAVAGe (1970), Mechanism of the Chilean earthquakes of May 21 and 22, 1960, Geol. Soc. Am. Bull. 81, 1001-1030.

RUFF, L. J., Fault asperities inferred from seismic body waves, in Earthquakes: Observation, Theory, and Observation (edited by H. Kanamori and E. Boschi) (North Holland, New York, 1983) pp. 251-276.

RufF, L. and H. Kanamori (1980), Seismicity and the subduction process, Phys. Earth Planet. Int. 23, $240-252$.

RUFF, L. and H. KANAMORI (1983a), Seismic coupling and uncoupling at subduction zones, Tectonophysics $99,99-117$.

RUFF, L. and H. KANAMORI (1983b), The rupture process and asperity distribution of three great earthquakes from long-period diffracted P-waves, Phys. Earth Planet. Int. 31, 202-230.

Ruff, L., H. KanAmori, and L. SyKes (1985), The 1957 great Aleutian earthquake, EOS 66, 298 (abstract).

SCHOLL, D. W., M. S. MARLOW, and A. K. CoOPER, Sediment subduction and offscraping at Pacific margins, in Island Arcs, Deep Sea Trenches, and Back-arc, Basins (edited by M. Talwani and W. C. Pitman III) (American Geophysical Union, Washington D.C., 1977) pp. 199-210.

SChOll, D. W., R. Von Huene, T. L. Vallier, and D. G. Howell (1980), Sedimentary masses and concepts about tectonic processes at underthrust margins, Geology 8, 564-568. 
SCHWARTZ, S. Y. and L. J. RUFF (1987), Asperity distribution and earthquake occurrence in the southern Kurile Islands arc, Phys. Earth Planet. Int. 49, 54-77.

SYKES, L. R. (1971), Aftershock zones of great earthquakes, seismicity gaps, and earthquake prediction for Alaska and the Aleutians, J. Geophys. Res. 76, 8021-8041.

SPENCE, W. (1986), The 1977 Sumba earthquake series: evidence for slab pull force acting at a subduction zone, J. Geophys. Res. 91, 7225-7239.

TAJIMA, F. and H. KANAMORI (1985), Global survey of aftershock area expansion patterns, Phys. Earth Planet. Int. 40, 77-134.

UYEDA, S. and H. KANAMORI (1979), Back-arc opening and the mode of subduction, J. Geophys. Res. $84,1049-1061$.

Von Huene, R., M. Langseth, N. Nasu, and H. Okada (1982), A summary of the Cenozoic tectonic history along the IPOD Japan Trench transect, Geol. Soc. Am. Bull. 93, 829-846.

WANG, C. (1980), Sediment subduction and frictional sliding in a subduction zone, Geology 8, 530-533.

(Received August 13, 1986, revised February 29, 1988, accepted April 11, 1988) 